\title{
Sex ratio in Gomphidae (Odonata) at emergence: is there a relationship with water temperature?
}

\author{
Anna Farkas ${ }^{1 *}$, Tibor Jakab², Ole Müller ${ }^{3}$, Arnold Móra ${ }^{4}$, Ibolya Lajter ${ }^{1}$ and György \\ Dévai $^{1}$
}

Department of Hydrobiology, University of Debrecen, Egyetem tér 1, H-4032 Debrecen, Hungary, flavipes@gmail.com, ibi113@freemail.hu, devai.gyorgy@science.unideb.hu

Kossuth L. Secondary Grammar-School, Baross Gábor 36, H-5350 Tiszafüred, Hungary, jkbtbr@gmail.com

Carl-Friedrich-Gauß-Gymnasium, Secondary Grammar-School, Fridrich-Ebert-Straße 52, 15234 Frankfurt (Oder), Germany, mueller.ole@googlemail.com

Hungarian Academy of Sciences, Centre for Ecological Research, Balaton Limnological Institute, Klebelsberg Kuno 3, H-8237 Tihany, Hungary, mora.arnold@okologia.mta.hu

*Corresponding Author: flavipes@gmail.com, +36 209859345 


\begin{abstract}
Although the sex ratio of Odonata at emergence has received much attention, we are still far from understanding the exact causes of its variability and imbalance. In this paper we studied the sex ratios at emergence in natural populations of two Gomphus species based on samples of exuviae taken from two European lowland rivers. We hypothesized a possible relationship between the water temperature during larval development and the sex ratio at emergence. Sex ratio records exhibited no consistent bias towards one sex but varied between habitats and years in both species. We found correlations between sex ratio and water temperature in the year preceding emergence. Furthermore, the correlation between sex ratios and water temperature was in opposite directions in the two congeneric species, which may be attributed to differences in their voltinisms. We conclude that the effect of water temperature can be mediated through cohort-splitting; temperature-dependent development of minor cohorts, including unequal proportions of males and females due to the faster development of male larvae, affects the sex ratio at emergence. The supposed effect does not cause a long-term consistent bias, but may explain the year-to-year variations.
\end{abstract}

Keywords: dragonfly; Gomphus flavipes; Gomphus vulgatissimus; Rivers Tisza and Szamos; voltinism; cohort-splitting; exuviae

\title{
Introduction
}

The sex ratio of Odonata at emergence has received much attention. Several reviews, summarizing all records available (Corbet, 1983, 1999; Corbet \& Hoess, 1998; Lawton, 1972), are consistent in the main conclusions that sex ratios at emergence often exhibit an imbalance; and that this imbalance indicates a slight excess of females in the Anisoptera and the opposite in the Zygoptera. However, besides this general tendency, sex ratios can differ greatly among taxa or even within a species (Corbet \& Hoess, 1998).

It has long been known that sex determination in Odonata in almost all cases is of the $\mathrm{XO} / \mathrm{XX}$ type, the male being the heterogametic sex (Kiauta, 1969). This mechanism produces a sex ratio of unity in the zygote. Any variability and imbalance in sex ratios observed at emergence is therefore related to the egg and/or larval stage (Corbet \& Hoess, 1998). Several assumptions and hypotheses have so far been described to explain the biased sex ratios (Baker et al., 1992; Corbet, 1957; Fuselier et al., 2007; Gribbin \& Thompson, 1991; Johansson et al., 2005; Lawton, 1972; Purse \& Thompson, 2003; Wong-Muñoz et al., 2011). Yet, as far as we know, there is little evidence supporting any of these hypotheses. Hence, the causes of sexratio imbalance remained largely unknown, as did its biological significance (see Corbet, 1999).

The majority of previous studies on sex ratios at emergence focused on a simple scenario when the sex ratio exhibits a consistent bias towards one sex in a given species (Crowley \& Johansson, 2002; Falck \& Johansson, 2000; Fuselier et al., 2007; Johansson et al., 2005; Wong-Muñoz et al., 2011). However, many species show widely varying sex ratios between sites and years without a consistent bias (e.g. Corbet \& Hoess 1998; Müller 1995). This suggests that environmental factors may be influential in altering the sex ratios, although the correlation between them is yet to be identified (Corbet \& Hoess 1998).

In temperate regions, besides photoperiod, water temperature also plays a major role in larval development, affecting larval growth rate, seasonal regulation and voltinism (Corbet, 1999). At given latitude, exposed to the same photoperiod, differences in larval development are mainly attributed to different temperature regimes (cf. Müller et al., 2000). Since the variability in the sex ratio is most likely to be related to the larval stage (see above), we 
hypothesize a possible relationship between the water temperature during larval development and the sex ratio at emergence.

To test this hypothesis in this paper we studied natural populations of two riverine dragonfly species (Odonata: Gomphidae), Gomphus flavipes flavipes (Charpentier, 1825) and Gomphus vulgatissimus (Linnaeus, 1758). To our knowledge, it was the first attempt to investigate the relationship between sex ratio and water temperature.

\section{Materials and methods}

\section{Sampling sites and data collection}

Sex ratio records of $G$. flavipes and $G$. vulgatissimus were based on the systematic collections of exuviae. Collections were carried out at four different sites along the Tisza river system in Northeast Hungary: (1) along the upper reach of the River Tisza at Jánd, upstream the firth of River Szamos; (2) along the upper reach of the River Tisza at Vásárosnamény, downstream the firth of River Szamos; (3) along the River Szamos at Olcsva, near the confluence; (4) along the dammed middle reach of the River Tisza between Tiszacsege and Tiszafüred (henceforth Tiszafüred) (Table 1). The three sites close to each other (1-3) were sampled in the same year (from late April to mid August in 2008), while the dammed site much further downstream (4) in four different years (from late April/early May to mid August in the years 2001-2003 and 2009). The study sites represented a range of hydrological and hydromorphological conditions. Furthermore, both different sites and years were exposed to various temperature regimes.

The collections of exuviae were made on standardized areas, $20 \mathrm{~m}$ long stretches of the river banks. The stretches at a given sampling site differed in river bank characteristics ranging from almost flat to steep bank normally covered with sandy sediment, but with paving at certain stretches. Riparian vegetation also varied from dense to scattered stands of trees or bushes (mainly Populus and Salix) with different undergrowth cover (especially Rubus). During collections the riverside ground and the vegetation were searched extensively for the moulted exuviae in an area of the bank $6 \mathrm{~m}$ in width. All the exuviae found were collected and later counted, identified and sexed for each day.

Samples were taken regularly and frequently during the whole emergence period (see Farkas et al., 2012); daily for the most part of the emergence period at sites 1-3, where the water level often changes and twice a week at the dammed site, where the water level is almost constant due to the barrage.

Sampling methods met the criteria listed by Corbet \& Hoess (1998) for ensuring that sex ratio data are accurate and comparable. Due to the low densities though, the sample size sometimes did not exceed the recommended minimum of 99 exuviae. We considered this in our analyses (see below).

Sex ratio was expressed as a percentage of males $\left(\%{ }^{\Uparrow}\right)$ of the total number of exuviae collected during the whole emergence period. Percentages of males were also calculated for distinct periods of emergence: $\%{ }^{\lambda}$ from the beginning of emergence until $\mathrm{EM}_{25}$ and $\mathrm{EM}_{35}$ was reached (\% $\% \mathrm{EM}_{0-25}$ and $\%{ }^{\lambda} \mathrm{EM}_{0-35}$ respectively), as well as $\%{ }^{\lambda}$ between $\mathrm{EM}_{75}$ and $\mathrm{EM}_{100}$ and between $\mathrm{EM}_{90}$ and $\mathrm{EM}_{100}\left(\%{ }^{\lambda} \mathrm{EM}_{75-100}\right.$ and \% ${ }^{\lambda} \mathrm{EM}_{90-100}$ respectively). The former represent distribution of the sexes during early phases of emergence, while the latter represent the late phases.

Long-term (1989-2009) water temperature data for the sampling sites were obtained from the Environmental and Water Management Directorate of the Tiszántúl Region and from an internet database (http://www.vizadat.hu). Water temperature data were derived from the nearest measuring stations and were measured daily at 7:00 CET by the local Water Management Directorates. 
In order to study the effect of water temperature on sex ratios, the mean temperatures of two distinct periods of larval development were used. At our sampling sites (at $47-48^{\circ} \mathrm{N}$ in two medium-sized rivers), life cycles of 2 to 3 years long are suggested for both species (Braune et al., 2008; Müller, 1995; Müller et al., 2000; Söndgerath et al., 2012). Therefore, water temperatures from two years preceding emergence were taken into account. This time window should cover the major part of the larval stage. However, the period when larval growth is interrupted (from diapause induction until spring when rising temperatures allow further development) should be excluded. Due to the fact that day length and temperature thresholds for diapause are variable in Odonata (Corbet, 1999; Flenner et al., 2010; Norling, 1984b) and no accurate data on these thresholds are available for the studied species, a relatively broad period from 1 March to 30 September was included in the analyses. Two types of temperature variables were used. First, we calculated the mean water temperature for the period from 1 March to 30 September for both years separately ( $\mathrm{T}_{-2}$ : mean water temperature from 1 March to 30 September two years before emergence; $T_{-1}$ : mean water temperature from 1 March to 30 September one year before emergence). In addition, we used the temperature difference $\left(\Delta \mathrm{T}_{-2}, \Delta \mathrm{T}_{-1}\right)$ between the actual mean temperature $\left(\mathrm{T}_{-2}, \mathrm{~T}_{-1}\right)$ and the long-term mean temperature ( $\mathrm{T}_{20}$, encompassing 1989-2009) of the same period, i.e., 1 March to 30 September.

\section{Statistical analyses}

To reveal the relationship between the sex ratio and water temperature, percentages of males (\% $\%$, \% $\mathrm{EM}_{0-25}, \% \mathrm{EM}_{0-35}, \% \mathrm{O}^{\lambda} \mathrm{EM}_{75-100}$ and \% $\left.\mathrm{O}^{\lambda} \mathrm{EM}_{90-100}\right)$ were used as dependent and temperature data $\left(\mathrm{T}_{-2}, \mathrm{~T}_{-1}, \Delta \mathrm{T}_{-2}, \Delta \mathrm{T}_{-1}\right)$ as independent variables in correlation tests. We used Pearson correlation, since all datasets had normal distribution (Jarque-Bera test, $\mathrm{p}>0.05$ in all cases).

First, tests were run including data from Tiszafüred $(\mathrm{N}=4)$ only, which are likely to represent more reliable sex ratio records because of the higher exuviae numbers exceeding the recommended minimum of 99 exuviae. Thereafter, we ran the same test including all sample sites $(\mathrm{N}=7)$. Although, in this case some sex ratio records were based on less than 99 exuviae, these results still may contribute to revealing the main tendencies. In the latter tests we utilized only $\Delta \mathrm{T}_{-2}$ and $\Delta \mathrm{T}_{-1}$ temperature variables to exclude local temperature differences between the sampling sites. For statistical analyses the program package PAST (Hammer et al., 2001) was used.

\section{Results}

No obvious bias towards one sex could be detected in either species, but sex ratio varied between sites and years from a slight excess of females to slight excess of males in G. flavipes (48.0-53.2\% males), and ranged from a somewhat higher excess of females to slight excess of males in G. vulgatissimus (43.2-52.0\% males) (Table 2).

$\mathrm{T}_{-1}$ was slightly higher than $\mathrm{T}_{20}$ at all sites and in every year, and the difference was negative in only one case. Similarly, $\mathrm{T}_{-2}$ was lower than $\mathrm{T}_{20}$ only in two cases (Table 3 ). In addition, no obvious trends could be observed in changes of $\Delta \mathrm{T}_{-1}$ and $\Delta \mathrm{T}_{-2}$.

$\mathrm{T}_{-2}$ and $\Delta \mathrm{T}_{-2}$ temperature variables were not correlated with $\% \hat{\delta}$, but $\mathrm{T}_{-1}$ and $\Delta \mathrm{T}_{-1}$ showed a significant relationship with $\%{ }^{\lambda}$. These correlations were positive in $G$. flavipes, while negative in G. vulgatissimus. Moreover, $\%{ }^{\lambda} \mathrm{EM}_{75-100}$ and $\% \overbrace{}^{\lambda} \mathrm{EM}_{90-100}$ were in strong positive correlation with $\Delta \mathrm{T}_{-1}$ in $G$. flavipes (Table 4), although the relationships were only significant when all sites were included in the analysis.

\section{Discussion}


In our study, neither $G$. flavipes nor $G$. vulgatissimus exhibited a clear bias towards one sex, but both had variable sex ratios. This result is consistent with some long-term studies that recorded no constant bias, but found great inter-year variability. Kern (1999) reported male ratios of $42.5-52.9 \%$ for G. vulgatissimus from a small stream, while Müller (1995) demonstrated male ratios of $30.7-72.4 \%$ for $G$. vulgatissimus and $40.1-51.0 \%$ for G. flavipes from the River Oder. In two short-term studies much more similar sex ratios were also recorded for G. vulgatissimus: Beutler (1986) reported male ratios of $41.8 \%$ and $46.1 \%$ from the River Spree, while Westermann et al. (1995) found male ratios of $50.0 \%$ and $50.2 \%$ at two different sites along the Upper Rhine.

Despite the small dataset used in this study our results suggest that a relationship exists between water temperature in the year preceding emergence and the sex ratio at emergence. However, the way in which temperature affects the sex ratio is still unclear. Under natural conditions it is unlikely that water temperature can change to an extent that would be lethal to the larvae. Therefore, water temperature during larval development may have indirect effect on the sex ratio at emergence. Sex-related response to varying water temperature was described by De Block \& Stoks (2003) but such responses were not examined in our study.

However, sex-specific effect of temperature is expected to be similar in the two closely related Gomphus species (with overlapping microdistribution, similar behavior and prey organisms; see Müller, 1995). Contrary to this expectation the correlation between water temperature and sex ratios was of opposite direction in the two species, being negative in $G$. vulgatissimus, but positive in G. flavipes. Therefore, it is reasonable to suggest that the correlation might be attributable to other developmental characteristics. One possible explanation is related to voltinism and cohort-splitting, along with the faster development of males. Although this explanation is largely theoretical, it is supported by our results if the following elements are taken into consideration.

It has been reported that cohort-splitting (a part of a year-class emerges either one year before (Corbet, 1957) or after (Norling, 1984a) the majority of that year-class) can influence the sex ratio; in Anax imperator a variably developed univoltine cohort late in the emergence period with female predominance affected the sex ratio at emergence (Corbet, 1957). Cohortsplitting is well documented in gomphids (e.g. Aoki, 1999; Ferreras-Romero et al., 1999) and also in the studied species (Müller, 1995). Among its causes, water temperature and intraspecific competition for food have been stressed (e.g. Banks \& Thompson, 1987; Corbet, 1957; Norling, 1984a). Prey organisms, especially chironomids, are abundant in the River Tisza (e.g. Móra et al., 2008), providing a nearly unlimited food resource for the gomphid larvae. Therefore, water temperature is the most likely to be playing a major role in splitting year-classes in our study and the size of the minor cohort may vary year to year depending on the actual temperature regime.

The unequal proportions of the sexes in the minor cohort may derive from the faster development of males than females: males that emerge earlier may have higher mating success, whereas it may be advantageous for females to develop longer, emerge at larger size and thus be more fecund (e.g. Corbet, 1999). If so, cohort-splitting causes a 1-year earlier emerging cohort to contain a higher proportion of males, while a 1-year later emerging cohort contains a higher proportion of females. The faster development of male larvae has been demonstrated for a number of species by laboratory studies (Baker et al., 1992; Fuselier et. al 2007; Mikolajewski et al., 2005), and may also be indicated by protandry, which is common in gomphids (e.g. Aoki, 1999; Lutz \& McMahan, 1973; Müller, 1995; Suhling \& Müller, 1996; Westermann et al., 1995) and was exhibited in the populations studied here (see Jakab 2006). 
The voltinism of Odonata is relatively flexible, depending on photoperiod and water temperature in temperate regions (Braune et al., 2008; Corbet et al., 2006). At our sampling sites life cycles 2 to 3 years long are suggested for both studied species (Müller, 1995; Müller et al., 2000; Söndgerath et al. 2012). However, there is evidence that the development of $G$. vulgatissimus can vary greatly (from 1 to 4 years) between different habitats (Müller, 2000; Söndgerath et al., 2012), while our knowledge on the life cycle of G. flavipes is more limited (Müller, 1995).

As has been demonstrated, larval development of $G$. vulgatissimus could be finished within two years in warm and shallow rivers (Müller et al., 2000; Söndgerath et al., 2012). Similarly, a 2-year life cycle was predicted for this species up to $\mathrm{N} 50^{\circ}$, based on modeling population dynamic along a latitudinal gradient (Braune et al., 2008). In our study the Rivers Tisza and Szamos met these criteria. In G. vulgatissimus, assuming a 2-year major and a 3-year minor cohort (Fig.1), the statistical correlations between sex ratios at emergence and the water temperature in the previous year $\left(\mathrm{T}_{-1}, \Delta \mathrm{T}_{-1}\right)$ may be explained as follows. After a year with higher water temperature $\left(\mathrm{t}_{-1}\right)$, faster larval development can result in fewer individuals of $G$. vulgatissimus emerging one year later $\left(\mathrm{t}_{1}\right)$ than the majority of that year class. This means that the 3-year minor cohort is relatively small, thus more females of the year-class emerge in their second year $\left(\mathrm{t}_{0}\right)$. This causes a decreased proportion of emerging males in $t_{0}$ resulting in a negative statistical correlation between sex ratio and water temperature. After a year with lower water temperature $\left(\mathrm{t}_{-1}\right)$, slower larval development can result in more individuals of $G$. vulgatissimus emerging one year later $\left(\mathrm{t}_{1}\right)$ than the majority of that year class. Due to their faster development, relatively fewer $G$. vulgatissimus males than females of the year-class extend their larval stage to the third year $\left(\mathrm{t}_{1}\right)$. This results a higher proportion of emerging males in $t_{0}$, thus supporting the negative statistical correlation between sex ratios and water temperature. Although it was not confirmed by the correlation tests, this mechanism can also lead to a negative correlation between water temperature and male ratio at the end of the emergence (\% $\delta^{\lambda} \mathrm{EM}_{75-100}$ and $\left.\%{ }^{\lambda} \mathrm{EM}_{90-100}\right)$. One reason for that these correlations could not be detected may be the small numbers of exuviae. Moreover, for G. vulgatissimus in the River Oder Müller (1995) suggested a more complex scenario of cohort-splitting, with more than two cohorts emerging in the same season.

In contrast, with $G$. flavipes having a similar life cycle the positive correlation between sex ratio and water temperature cannot be explained in the previous way, suggesting that the development of this species is different from that of G. vulgatissimus. Assuming a 3-year major and a 2-year minor cohort (Fig.1) however, the results can be easily interpreted. After a year with higher water temperature $\left(\mathrm{t}_{-}\right)$, faster larval development can result in more individuals of $G$. flavipes emerging one year earlier $\left(\mathrm{t}_{0}\right)$ than the majority of that year class. Accordingly, the 2-year minor cohort is more developed. In addition, males develop faster than females, meaning that relatively more males of the year-class emerge in their second year $\left(\mathrm{t}_{0}\right)$ and relatively more females of that year-class emerge in their third year $\left(\mathrm{t}_{1}\right)$. Due to this an increased proportion of emerging males appears in $t_{0}$, resulting in a positive statistical correlation between the sex ratio and water temperature. After a year with lower water temperature $\left(\mathrm{t}_{-1}\right)$, slower larval development can result in fewer individuals of $G$. flavipes emerging one year earlier $\left(\mathrm{t}_{0}\right)$ than the majority of that year class. Thus, the 2-year minor cohort is less developed, which means that more males of the year-class emerge in their third year $\left(t_{1}\right)$. This decreases the proportion of emerging males in $t_{0}$, contributing to the positive statistical correlation between sex ratio and water temperature. Moreover, the 2-year minor cohort is liable to emerge later in season than the majority, which was confirmed by the correlation tests (positive correlation between water temperature and $\%{ }^{\lambda} \mathrm{EM}_{75-100}$ and $\left.\%{ }^{\lambda} \mathrm{EM}_{90-100}\right)$. 
Additionally, in this explanation $t_{-2}$ corresponds to the year of hatching in both species (Fig. 1). In the year of hatching larval growth is restricted to a relatively short period, and therefore the water temperature of this year may have less influence on the development compared to that of the following year. This could explain why $T_{-2}$ and $\Delta T_{-2}$ (the water temperature in the year of hatching) were not correlated with sex ratio in the statistical tests.

Summarizing the relationships discussed above, the effect of water temperature on the sex ratio at emergence may be mediated through cohort-splitting. A variably developed minor cohort, including unequal proportions of males and females, may affect the sex ratio, where the size of this minor cohort depends on the water temperature. Note that higher proportion of males do not necessarily exceed 50\% in these cases, it simply means an increase in proportion compared to the preceding or subsequent year. Hence we can conclude that the effect of water temperature may not cause a long-term consistent bias, but might explain the year-to-year variations in sex ratio.

The various studies on sex ratio of Odonata at emergence imply that mechanisms acting on sex ratio are complex (see Introduction). Nevertheless, in accordance with our findings, in the future studies it would be reasonable to take into account water temperature, voltinism and cohort-splitting, as potential causes of the variability in sex ratios.

\section{Acknowledgements}

We wish to thank the Upper-Tisza Environmental and Water Directorate, personally Gáspár Bodnár, Károly Uray and the Tóth family, for providing the facilities for our studies; the Environmental and Water Management Directorate of the Tiszántúl Region for access to water temperature data. The publication was supported by the TÁMOP-4.2.2/B-10/1-2010-0024 project. The project was co-financed by the European Union and the European Social Fund.

\section{References}

Aoki, T. (1999). Larval development, emergence and seasonal regulation in Asiagomphus pryeri (Selys) (Odonata: Gomphidae). Hydrobiologia, 394, 179-192.

Baker, R.L., Forbes, M.R.L. \& Proctor, H.C. (1992). Sexual differences in development and behaviour of larval Ischnura verticalis (Odonata: Coenagrionidae). Canadian Journal of Zoology, 70, 1161-1165.

Banks, M.J. \& Thompson, D.J. (1987). Regulation of damselfly populations: the effects of larval density on larval survival, development rate and size in the field. Freshwater Biology, 17, 357-365.

Beutler, H. (1986). Zur Schlupfrate und zum Geschlechterverhältnis einheimischer Großlibellen (Anisoptera) (Odonata). Entomologische Abhandlungen, 49(10), 201-209.

Braune, E., Richter, O., Söndgerath, D. \& Suhling, F. (2008). Voltinism flexibility of a riverine dragonfly along thermal gradients. Global Change Biology, 14, 470-482.

Corbet, P.S. (1957). The life-history of the emperor dragonfly Anax imperator Leach (Odonata: Aeshnidae). Journal of Animal Ecology, 26, 1-69.

Corbet, P.S. (1983). A biology of dragonflies. Facsimile reprint. Faringdon: EW Classey Ltd

Corbet, P.S. (1999). Dragonflies: behaviour and ecology of Odonata. Colchester: Harley Books

Corbet, P.S. \& Hoess, R. (1998). Sex ratio of Odonata at emergence. International Journal of Odonatology, 1, 99-118.

Corbet, P.S., Suhling, F. \& Soendgerath, D. (2006). Voltinism of Odonata: a review. International Journal of Odonatology, 9, 1-44.

Crowley, P.H. \& Johansson, F. (2002). Sexual dimorphism in Odonata: age, size, and sex ratio. Oikos, 96, 364378.

De Block, M. \& Stoks, R. (2003). Adaptive sex-specific life history plasticity to temperature and photoperiod in a damselfly. Journal of Evolutionary Biology, 16, 986-995.

Falck, J. \& Johansson, F. (2000). Patterns in size, sex ratio and time at emergence in a south Swedish population of Sympetrum sanguineum (Odonata). Aquatic Insects, 22, 311-317.

Farkas, A., Jakab, T., Tóth, A., Kalmár, A.F. \& Dévai, Gy. (2012). Emergence patterns of riverine dragonflies (Odonata: Gomphidae) in Hungary: variations between habitats and years. Aquatic Insects, 34(Suppl. 1), 77-89. 
Ferreras-Romero, M., Atienzar, M.D. \& Corbet, P.S. (1999). The life cycle of Onychogomphus uncatus (Charpentier, 1840) (Odonata: Gomphidae) in the Sierra Morena Mountains (southern Spain): an example of protracted larval development in the Mediterranean basin. Archiv für Hydrobiologie, 144, 215-228.

Flenner, I., Richter, O. \& Suhling, F. (2010). Rising temperature and development in dragonfly populations at different latitudes. Freshwater Biology, 55, 397-410.

Fuselier, L., Decker, P., Lunski, J. Mastel, T. \& Skolness, S. (2007). Sex differences and size at emergence are not linked to biased sex ratios in the Common Green Darner, Anax junius (Odonata: Aeshnidae). Journal of Freshwater Ecology, 22, 107-117.

Gribbin, S.D. \& Thompson, D.J. (1991). Emergence of the damselfly Pyrrhosoma nymphula (Sulzer) (Zygoptera: Coenagrionidae) from two adjacent ponds in northern England. Hydrobiologia, 209, $123-131$.

Hammer, Ø., Harper, D.A.T. \& Ryan, P.D. (2001). PAST: Paleontological statistics software package for education and data analysis. Palaeontologia Electronica, 4/1, 1-9. http://palaeoelectronica.org/2001_1/past/issue1_01.htm

Jakab, T. (2006). A Tisza-tó és a Közép-Tisza szitakötő-fajegyütteseinek (Insecta: Odonata) összehasonlító elemzése. PhD Dissertation, Debrecen: University of Debrecen

Johansson, F., Crowley, P.H. \& Brodin, T. (2005). Sexual size dimorphism and sex ratios in dragonflies (Odonata). Biological Journal of the Linnean Society, 86, 507-513.

Kern, D. (1999). Langzeituntersuchungen zur Populationsentwicklung und zum Lebenszyklus von Gomphus vulgatissimus (Linnaeus) an einem nordwestdeutschen Fließgewässer (Anisoptera: Gomphidae). Libellula, $18,107-132$.

Kiauta, B. (1969). Sex chromosomes and sex determining mechanisms in Odonata, with a review of the cytological conditions in the family Gomphidae, and references to the karyotypic evolution of the order. Genetica, 40, 127-157.

Lawton, J.H. (1972). Sex ratios in Odonata larvae, with particular reference to the Zygoptera. Odonatologica, 1, 209-219.

Lutz, P.E. \& McMahan, E.A. (1973). Five-year patterns of emergence in Tetragoneuria cynosura and Gomphus exilis (Odonata). Annals of the Entomological Society of America, 66, 1343-1348.

Mikolajewski, D.J., Brodin, T., Johansson, F. \& Joop, G. (2005). Phenotypic plasticity in gender specific lifehistory: effect of food availability and predation. Oikos, 110, 91-100.

Móra, A., Csépes, E., Tóth, M. \& Dévai, Gy. (2008). Spatio-temporal variations of macroinvertebrate community in the Tisza River (NE Hungary). Acta Zoologica Academiae Scientiarum Hungaricae, 54, 181190.

Müller, O. (1995). Ökologische Untersuchungen an Gomphiden (Odonata: Gomphidae) unter besonderer Berücksichtigung ihrer Larvenstadien. Göttingen: Cuvillier Verlag

Müller, O., Schütte, C., Artmeyer, C., Burbach, K., Grand, D., Kern, D., Leipelt, K.G., Martens, A., Petzold, F., Suhling, F., Weihrauch, F., Werzinger, J. \& Werzinger, S. (2000). Entwicklungsdauer von Gomphus vulgatissimus: Einfluss von Gewässertyp und Klima (Odonata: Gomphidae). Libellula, 19, 175-198.

Müller, O., Schütte, C., Artmeyer, C., Burbach, K., Grand, D., Kern, D., Leipelt, K.G., Martens, A., Petzold, F., Suhling, F., Weihrauch, F., Werzinger, J. \& Werzinger, S. (2000). Entwicklungsdauer von Gomphus vulgatissimus: Einfluss von Gewässertyp und Klima (Odonata: Gomphidae). Libellula, 19, 175-198.

Norling, U. (1984a). The life cycle and larval photoperiodic responses of Coenagrion hastulatum (Charpentier) in two climatically different areas (Zygoptera: Coenagrionidae). Odonatologica, 13, 429-449.

Norling, U. (1984b). Photoperiodic control of larval development in Leucorrhinia dubia (Vander Linden): A comparison between populations from Northern and Southern Sweden (Anisoptera: Libellulidae). Odonatologica, 13, 529-550.

Purse, B.V. \& Thompson, D.J. (2003). Emergence of the damselflies, Coenagrion mercuriale and Ceriagrion tenellum (Odonata: Coenagrionidae), at their northern range margins, in Britain. European Journal of Entomology, 100, 93-99.

Söndgerath, D., Rummland, J. \& Suhling, F. (2012). Large spatial scale effects of rising temperatures: modelling a dragonfly's life cycle and range throughout Europe. Insect Conservation and Diversity, 5, 461-469.

Suhling, F. \& Müller, O. (1996). Die Flußjungfern Europas (Gomphidae). Die neue Brehm-Bücherei 628. Magdeburg, Heidelberg, Berlin, Oxford: Westarp \& Spektrum

Westermann, K., Westermann, S., Heitz, A. \& Heitz, S. (1995). Schlüpfperiode, Schlüpfhabitat und Geschlechterverhältnis der Gemeinen Keiljungfer (Gomphus vulgatissimus) am südlichen Oberrhein. Naturschutz am südlicher Oberrhein, 1, 41-54.

Wong-Muñoz, J., Córdoba-Aguilar, A., Cueva del Castillo, R., Serrano-Meneses, M.A. \& Payne, J. (2011). Seasonal changes in body size, sexual size dimorphism and sex ratio in relation to mating system in an adult odonate community. Evolutionary Ecology, 25, 59-75. 


\section{TABLES}

Table 1. Characterization of the sampling sites and collection method

\begin{tabular}{|c|c|c|c|c|c|c|c|c|c|c|}
\hline Collection site & $\begin{array}{l}\text { Geo- } \\
\text { coord. }\end{array}$ & $\begin{array}{c}\text { River } \\
\text { km }\end{array}$ & $\begin{array}{c}\text { River } \\
\text { width (m) }\end{array}$ & $\begin{array}{c}\text { Discharge } \\
\left(\mathrm{m}^{3} \mathrm{~s}^{-1}\right)\end{array}$ & $\begin{array}{l}\mathbf{T}_{\text {ann. }} \\
\left({ }^{\circ} \mathbf{C}\right)\end{array}$ & $\begin{array}{l}\mathbf{T}_{\text {Jan }} \\
\left({ }^{\circ} \mathrm{C}\right)\end{array}$ & $\begin{array}{l}\mathbf{T}_{\text {July }} \\
\left({ }^{\circ} \mathbf{C}\right)\end{array}$ & $\begin{array}{l}\text { Collection } \\
\text { season }\end{array}$ & $\begin{array}{l}\text { Sampling } \\
\text { unit (m) }\end{array}$ & $\begin{array}{l}\text { Collection } \\
\text { frequency }\end{array}$ \\
\hline $\begin{array}{l}\text { Tiszafüred, R. } \\
\text { Tisza, l.b. }\end{array}$ & 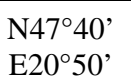 & $\begin{array}{c}433- \\
450\end{array}$ & $\sim 175$ & 574 & 12 & 1.2 & 23.3 & $\begin{array}{c}2001- \\
2003,2009\end{array}$ & $6 \times 20$ & $\begin{array}{l}\text { two times } \\
\text { per week }\end{array}$ \\
\hline $\begin{array}{l}\text { Jánd, R. Tisza, } \\
\text { r.b. }\end{array}$ & $\begin{array}{l}\mathrm{N} 48^{\circ} 06^{\prime} \\
\mathrm{E}^{\prime} 2^{\circ} 21^{\prime}\end{array}$ & $\begin{array}{c}687- \\
689\end{array}$ & $\sim 117$ & 249 & 10 & 0.8 & 20.3 & 2008 & $3 \times 20$ & daily* \\
\hline $\begin{array}{l}\text { Vásárosnamény, } \\
\text { R. Tisza, l.b. }\end{array}$ & $\begin{array}{l}\mathrm{N} 48^{\circ} 07^{\prime} \\
\mathrm{E} 22^{\circ} 20^{\prime}\end{array}$ & $\begin{array}{c}684- \\
685\end{array}$ & $\sim 121$ & 392 & 10.5 & 0.9 & 21.3 & 2008 & $3 \times 20$ & daily* \\
\hline $\begin{array}{l}\text { Olcsva, R. } \\
\text { Szamos, l.b. }\end{array}$ & $\begin{array}{l}\mathrm{N} 48^{\circ} 05^{\prime} \\
\mathrm{E}^{\circ} 2^{\circ} 20^{\prime}\end{array}$ & $3-4$ & $\sim 62$ & 147 & 11 & 0.9 & 22 & 2008 & $3 \times 20$ & daily* \\
\hline
\end{tabular}

l.b.: left bank, r.b.: right bank; $\mathrm{T}_{\mathrm{ann}}$ : mean annual water temperature, $\mathrm{T}_{\mathrm{Jan}}$ : mean water temperature in January, $\mathrm{T}_{\text {July: }}$ mean water temperature in July (based on 20-year data)

*When emergence intensity decreased and seasonal floods moderated, the stretches were checked twice a week (in the last two weeks of the emergence at most)

Table 2. Sex ratios of the studied species at emergence

\begin{tabular}{|c|c|c|c|c|c|c|c|c|c|}
\hline Species & $\begin{array}{l}\text { Collection } \\
\text { site }\end{array}$ & $\begin{array}{l}\text { Collection } \\
\text { season }\end{array}$ & Onset & $\mathbf{N}$ & $\%$ & $\begin{array}{c}\% \overbrace{}^{\lambda} \\
\mathbf{E M}_{\mathbf{0 - 2 5}}\end{array}$ & $\begin{array}{c}\text { \%o } \\
\mathbf{E M}_{\mathbf{0} 35}^{\lambda}\end{array}$ & $\begin{array}{c}\% \overbrace{}^{\lambda} \\
\mathbf{E M}_{75-100}\end{array}$ & $\begin{array}{c}\%{ }^{\lambda} \\
\mathbf{E M}_{90-100}\end{array}$ \\
\hline \multirow[t]{7}{*}{ G. flavipes } & Tiszafüred & 2001 & 27 May & 1888 & 49.2 & 56.23 & 54.52 & 44.61 & 46.15 \\
\hline & & 2002 & 25 May & 3105 & 48.0 & 54.37 & 51.70 & 44.49 & 37.76 \\
\hline & & 2003 & 27 May & 4883 & 51.2 & 57.39 & 57.38 & 44.92 & 44.71 \\
\hline & & 2009 & 25 May & 3145 & 48.3 & 57.02 & 54.57 & 41.76 & 39.33 \\
\hline & Jánd & 2008 & 10 June & 54 & 51.9 & 57.14 & 51.36 & 46.15 & 64.29 \\
\hline & Vásárosnamény & 2008 & 1 June & 156 & 53.2 & 63.02 & 61.89 & 52.83 & 59.75 \\
\hline & Olcsva & 2008 & 31 May & 183 & 50.8 & 57.14 & 57.18 & 50.00 & 58.44 \\
\hline \multirow[t]{7}{*}{ G. vulgatissimus } & Tiszafüred & 2001 & 4 May & 250 & 48.8 & 62.71 & 62.83 & 36.07 & 28.25 \\
\hline & & 2002 & 4 May & 298 & 52.0 & 62.55 & 60.80 & 43.57 & 42.40 \\
\hline & & 2003 & 10 May & 209 & 44.0 & 48.77 & 47.75 & 38.16 & 33.30 \\
\hline & & 2009 & 28 April & 120 & 50.8 & 59.72 & 58.44 & 39.69 & 40.71 \\
\hline & Jánd & 2008 & 12 May & 66 & 43.9 & 78.24 & 62.75 & 12.50 & 13.79 \\
\hline & Vásárosnamény & 2008 & 6 May & 88 & 43.2 & 40.40 & 42.34 & 37.50 & 61.36 \\
\hline & Olcsva & 2008 & 3 May & 91 & 38.5 & 65.16 & 54.36 & 16.75 & 11.52 \\
\hline
\end{tabular}

Onset: onset of emergence; $\mathrm{N}$ : total number of exuviae that can be sexed; \% $\%$ : percentage of males of the total; $\%{ }^{\wedge} \mathrm{EM}_{0-25}$ : percentage of males of the total from the beginning of emergence until $\mathrm{EM}_{25}$ was reached; $\%{ }^{\lambda} \mathrm{EM}_{0-}$ ${ }_{35}$ : percentage of males of the total from the beginning of emergence until $\mathrm{EM}_{35}$ was reached; $\%{ }^{\lambda} \mathrm{EM}_{75-100}$ : percentage of males of the total between $\mathrm{EM}_{75}$ and $\mathrm{EM}_{100}$; \% $\overbrace{}^{\lambda} \mathrm{EM}_{90-100}$ : percentage of males of the total between $\mathrm{EM}_{90}$ and $\mathrm{EM}_{100}$ 
International Journal of Odonatology 16/4: 279-287., 2013

Table 3. Temperature characteristics of the study sites and years

\begin{tabular}{lcccccc}
\hline $\begin{array}{l}\text { Collection } \\
\text { site }\end{array}$ & $\begin{array}{c}\text { Collection } \\
\text { season }\end{array}$ & $\mathbf{T}_{\mathbf{2 0}}$ & $\mathbf{T}_{\mathbf{- 1}}$ & $\mathbf{\Delta} \mathbf{T}_{\mathbf{- 1}}$ & $\mathbf{T}_{\mathbf{- 2}}$ & $\mathbf{\Delta T}_{\mathbf{- 2}}$ \\
\hline Tiszafüred & 2001 & & 17.7 & 0.8 & 17.1 & 0.2 \\
& 2002 & & 17.0 & 0.1 & 17.7 & 0.8 \\
& 2003 & & 18.9 & 1.4 & 17.0 & 0.1 \\
& 2009 & & 16.8 & -0.1 & 18.5 & 1.6 \\
Jánd & 2008 & 14.3 & 15.6 & 1.3 & 14.0 & -0.3 \\
Vásárosnamény & 2008 & 15.0 & 16.9 & 1.9 & 15.8 & 0.8 \\
Olcsva & 2008 & 15.9 & 17.7 & 1.8 & 15.5 & -0.4 \\
\hline
\end{tabular}

$\mathrm{T}_{20}$ : mean water temperature from 1 March to 30 September based on 20-year data set; $\mathrm{T}_{-1}$ : mean water temperature from 1 March to 30 September one year before emergence; $\Delta T_{-1}$ : difference between $T_{-1}$ and $T_{20} ; T_{\text {. }}$ ${ }_{2}$ : mean water temperature from 1 March to 30 September two years before emergence; $\Delta \mathrm{T}_{-2}$ : difference between $\mathrm{T}_{-2}$ and $\mathrm{T}_{20}$

Table 4. Results of Pearson correlation. R values are recorded where correlation is significant (except two cases, where strong, although not significant correlations were found)

\begin{tabular}{lcccc}
\hline & \multicolumn{2}{c}{ Gomphus flavipes } & \multicolumn{2}{c}{ Gomphus vulgatissimus } \\
\hline Pairs of variables & Tiszafüred & All sites & Tiszafüred & All sites \\
$\%{ }^{\curvearrowright}-\mathrm{T}_{-1}$ & $0.9574^{*}$ & - & $-0.9460^{+}$ & - \\
$\%{ }^{\lambda}-\Delta \mathrm{T}_{-1}$ & $0.9574^{*}$ & $0.9086^{* *}$ & $-0.9464^{+}$ & $-0.9268^{* *}$ \\
$\% \mathrm{CM}_{75-100}-\Delta \mathrm{T}_{-1}$ & $\mathrm{~ns}(0.7162)$ & $0.8325^{*}$ & $\mathrm{~ns}$ & $\mathrm{~ns}$ \\
$\% \mathrm{CM}_{90-100}-\Delta \mathrm{T}_{-1}$ & $\mathrm{~ns}(0.8198)$ & $0.8161^{*}$ & $\mathrm{~ns}$ & $\mathrm{~ns}$ \\
\hline
\end{tabular}

$\%{ }^{\lambda}$ : percentage of males of the total; $\%{ }^{\lambda} \mathrm{EM}_{75-100}$ : percentage of males of the total between $\mathrm{EM}_{75}$ and $\mathrm{EM}_{100}$; $\%{ }^{\lambda} \mathrm{EM}_{90-100}$ : percentage of males of the total between $\mathrm{EM}_{90}$ and $\mathrm{EM}_{100} ; \mathrm{T}_{-1}$ : mean water temperature from 1 March to 30 September one year before emergence; $\Delta \mathrm{T}_{-1}$ : difference between $\mathrm{T}_{-1}$ and $\mathrm{T}_{20}$;

*: $\mathrm{p}<0.05,{ }^{* *}: \mathrm{p}<0.01,{ }^{+}$: marginally significant $(0.05<\mathrm{p}<0.06)$; ns: not significant, -: correlation was not analyzed (see Materials and methods) 
International Journal of Odonatology 16/4: 279-287., 2013

\section{FIGURE LEGENDS}

Figure 1. Predicted life cycles of (a) G. flavipes and (b) G. vulgatissimus to explain the relationship between water temperature and sex ratio through cohort-splitting $\left(\mathrm{t}_{-2}-\mathrm{t}_{1}\right.$ : the years of development) 